\title{
Differential inhibitory action of cationic amino acids on protein synthesis in pancreatic rat islets
}

\author{
C. Patzelt \\ Department of Physiological Chemistry, University of Würzburg, Würzburg, FRG
}

\begin{abstract}
Summary. The effect of cationic amino acids, i.e. L-arginine and L-lysine, on protein synthesis in isolated rat islets of Langerhans has been investigated. Except for prosomatostatin, the formation of islet proteins is strongly depressed by these amino acids. This effect can be demonstrated within a few minutes and is rapidly reversible. For proglucagon, efficient concentrations of arginine are in the range of 1 to $10 \mathrm{mmol} / \mathrm{l}$. The sensitivity of proinsulin formation to arginine is glucose-dependent: at $2.5 \mathrm{mmol} / 1$, inhibitory concentrations of arginine are 10 -fold lower than in the case of proglucagon. High glucose $(20 \mathrm{mmol} / 1)$ almost completely
\end{abstract}

protects proinsulin synthesis from this inhibition. The proteolytic conversion steps in hormonal precursor processing are not influenced by cationic amino acids as studied in intact islets and in a cell-free translational system. It is concluded that arginine and lysine inhibit protein synthesis in islet cells at the translational level. The release of these amino acids by prohormone conversion may exert a feed-back control on proinsulin formation that is modulated by glucose.

Key words: Pancreatic islets, prohormones, biosynthesis, arginine, lysine, glucose.
The intracellular conversion of prohormones is catalysed by specific proteases that recognise pairs of basic or cationic amino acids, i. e. arginine and lysine, at the prospective cleavage sites [1]. So far, it is not quite clear whether cationic amino acids that are released by this process are of any physiological importance.

Like several other amino acids, exogenously supplied arginine and lysine show a stimulatory action on the release of insulin, and arginine is also known to be a potent stimulus of glucagon secretion [2]. From biosynthetic studies, no evidence has been obtained for a concomitant stimulation of the synthesis of these hormones. Surprisingly, arginine has been reported to inhibit the formation of proinsulin [3] as well as that of glucagon [4].

Here, the action of arginine and lysine on islet protein synthesis has been investigated by incorporation of highly active $\left({ }^{35} \mathrm{~S}\right)$ methionine as a very sensitive indicator reaction. Only short labelling periods were thus employed at the end of the various incubation regimens. Labelled precursor proteins including preproinsulin and proinsulin [5], proglucagon [6] and prosomatostatin [7] were subsequently separated by gel electrophoresis and visualised by fluorography. The exclusive determination of proinsulin II by incorporation of $\left({ }^{35} \mathrm{~S}\right)$ methionine can be regarded as representative for insulin biosynthesis [8].

By this biosynthetic approach, the action of cationic amino acids was characterised including the timeand concentration-dependency, the specificity with regard to other amino acids, the site of action within the biosynthetic pathway, and the interaction with glucose.

\section{Materials and methods}

\section{Tissue preparation and incubation}

Pancreatic islets were isolated from inbred Wistar rats (180-350 g) by a modified collagenase procedure [9] (collagenase from clostridium histolyticum, Serva, Heidelberg, FRG). If not stated otherwise, batches of 100 islets were preincubated in $1.0 \mathrm{ml}$ Hanks' buffer, $1 \mathrm{mg}$ bovine serum albumin (BSA) per $\mathrm{ml}$, supplemented with glucose and amino acids as described for individual experiments. Thereafter, islets were pelleted, washed and incubated for $10 \mathrm{~min}$ in $100 \mu \mathrm{l}$ Hanks'buffer/BSA containing approximately $10 \mu \mathrm{Ci}\left({ }^{35} \mathrm{~S}\right)$ methionine ( $>800 \mathrm{Ci} / \mathrm{mmol}$, New England Nuclear, Dreieich, FRG) and the indicated additions. All incubations were done at $37^{\circ} \mathrm{C}$. Lysis of islets, sodium dodecylsulfate-polyacrylamide gel electrophoresis and fluorographic detection of labelled proteins have been described [5]. For quantitation of labelled prohormones, the respective bands were excised from fluorographed electrophoresis gels, dissolved in $500 \mu 1$ $30 \% \mathrm{H}_{2} \mathrm{O}_{2}$ at $70^{\circ} \mathrm{C}$ overnight and counted in $10 \mathrm{ml}$ Scinit-gel (Roth, Hanau, FRG). 


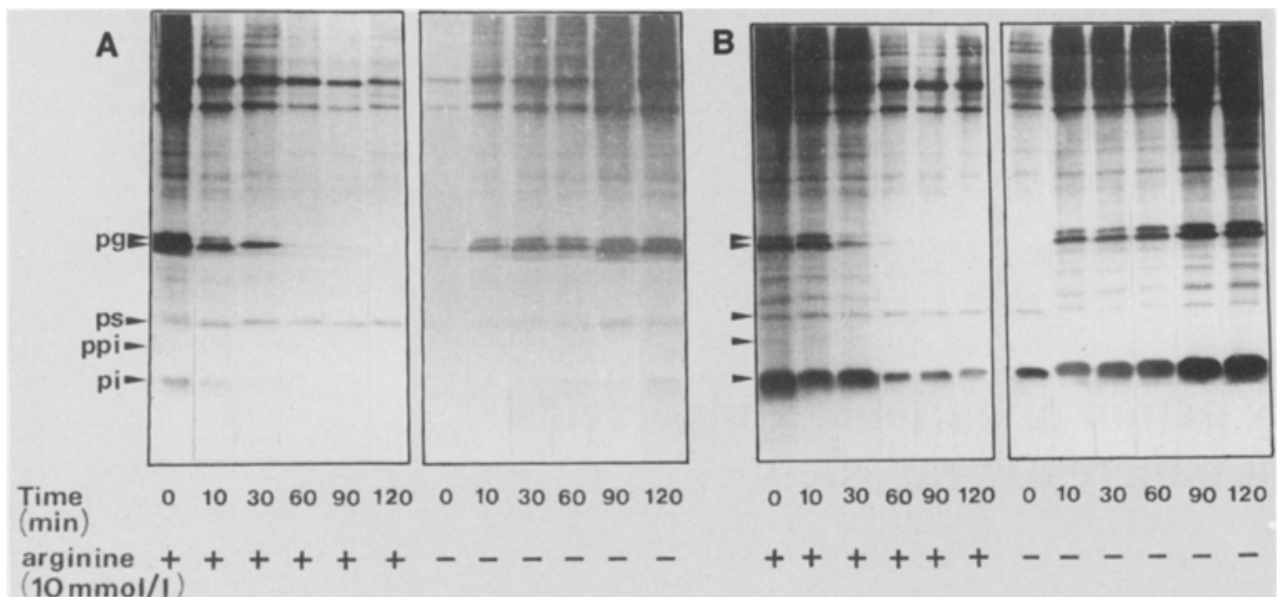

C

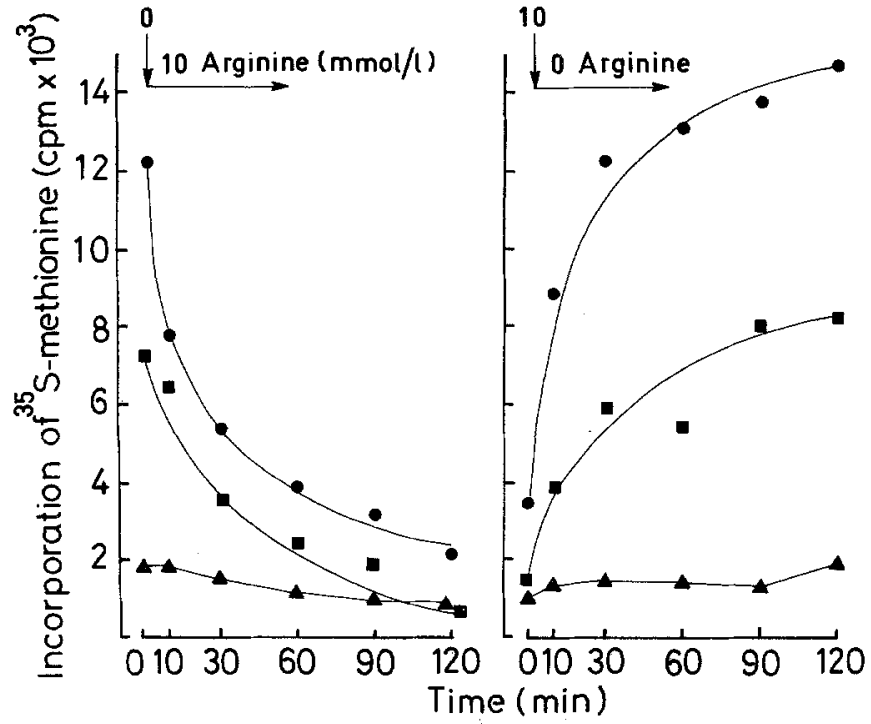

\section{Determination of amino acid uptake}

Samples of 100 islets were preincubated for $1 \mathrm{~h}$ in $7.5 \mathrm{mmol} / 1$ of glucose either in the absence or presence of $10 \mathrm{mmol} / \mathrm{l}$ of cationic amino acids as described above. Islets were then pelleted and supernatants were replaced by $100 \mu 1$ preincubation medium containing approximately $5 \mu \mathrm{Ci}\left({ }^{35} \mathrm{~S}\right)$ methionine and fluosescein isothiocyanate (FITC)-labelled BSA $(1 \mathrm{mg} / \mathrm{ml})$. The FITC content of this preparation [10] was $8.5 \mathrm{~mol}$ per mol of albumin. After $10 \mathrm{~min}$ incubation, islets were pelleted. $10 \mu \mathrm{l}$ aliqots from supernates were diluted to $1.0 \mathrm{ml}$ with $\mathrm{Na}$-phosphate $(10 \mathrm{mmol} / \mathrm{l})$, ph 7.0. Remaining supernatants were removed as far as possible and islets were dissolved in $100 \mu 12 \%$ sodium dodecylsulfate with boiling for $3 \mathrm{~min}$. Thereafter, islets lysates were diluted to $1.0 \mathrm{ml}$ with phosphate buffer. The fluorescence of diluted supernatants and lysates was measured in a fluorometer $(494 \mathrm{~nm} / 515 \mathrm{~nm})$. Samples were then transferred to scintillation vials with $10 \mathrm{ml}$ Scinti-gel and counted. From the readings of FITC-fluorescence the data for $\left({ }^{35} \mathrm{~S}\right)$ methionine uptake in islet lysates were corrected for contaminations from incubation medium.

\section{Cell-free translation and immunoprecipitation}

Islet mRNA was isolated by extraction in phenol-chloroform and chromatography on oligo(dT)cellulose(Bethesda Research Laboratories, BRL, Neu-Isenburg, FRG) [11]. For cell free translation in a nuclease-treated wheat-germ extract (BRL), $100 \mu \mathrm{l}$ of islet mRNA viously [13].

\section{Statistical analysis}

\section{Results}

Fig. 1. Time-dependency of the effect of arginine on prohormone biosynthesis in pancreatic islets.

Batches of 100 islets were preincubated for $60 \mathrm{~min}$ without (left panels) or with $10 \mathrm{mmol} / 1$ of L-arginine (right panels). Islets were then washed and subjected for the indicated periods to a second preincubation either with $10 \mathrm{mmol} / \mathrm{l}$ or arginine (left panels) or without arginine (right panels). Finally, islets were biosynthetically labelled with $\left({ }^{35} \mathrm{~S}\right)$ methionine for $10 \mathrm{~min}$ (see Materials and methods). A $2.5 \mathrm{mmol} / 1$ of glucose. B $7.5 \mathrm{mmol} / 1$ of glucose, $\mathbf{C}$ quantitation of $\mathbf{B}$ (means of 3 experiments), pi: proinsulin ( $)$, pg: proglucagon ( $\mathbf{\square})$, ps: prosomatostatin ( $\mathbf{\Delta})$, ppi: preproinsulin

(corresponding to 1000 islets) were incubated in a total volume of $300 \mu \mathrm{l}$ translation mixture containing $50 \mu \mathrm{Ci}\left({ }^{35} \mathrm{~S}\right)$ methionine and $20 \mu \mathrm{l}$ microsomal membranes $\left(\mathrm{OD}_{280}\right.$ approximately 50$)$ [12] where indicated. After $60 \mathrm{~min}$ incubation at $30^{\circ} \mathrm{C}$, samples were diluted in $1.0 \mathrm{ml}$ immunoprecipitation buffer [13]. Two $\mu \mathrm{l}$ of guinea pig anti-insulin serum (generously supplied by D.F. Steiner, Chicago Ill, USA) were added. Conditions for incubation, precipitation by a second antibody (anti guinea pig IgG, Miles, Naperville, Ill, USA), washing of pripitates and their electrophoretic analysis have been described pre-

Statistical significance levels were calculated by Student's t-test.

During studies on the influence of amino acids on protein synthesis in isolated islets, a strong inhibitory action of L-arginine was observed. Figure 1 shows the time-course of this effect for isolated islets incubated at $2.5 \mathrm{mmol} / 1$ (Fig. 1 A) or $7.5 \mathrm{mmol} / 1$ of glucose (Fig. 1 B and $1 \mathrm{C}$ ). The inhibitory action of $10 \mathrm{mmol} / 1$ of L-arginine concerns the formation of almost all islet proteins. It can be demonstrated already after $10 \mathrm{~min}$ and comes near to completion after $60 \mathrm{~min}$. If islets are preincubated in arginine, then washed and incubated further in arginine-free medium, the inhibition of protein synthesis is rapidly reversed. This inhibition is most evident for proglucagon formation, whereas prosomatostatin appears to be the only protein in the resolved molecular range whose synthesis remains alsmost unchanged. Proinsulin and most of the other, still unidentified islet proteins are completely inhibited by arginine when incubated in low glucose $(2.5 \mathrm{mmol} / 1$, Fig. 1A). At elevated glucose concentration $(7.5 \mathrm{mmol} /$ 1, Fig. 1 B and 1C) the inhibitory action of arginine is still demonstrable but incomplete.

Depending on arginine concentrations, the inhibitory influence on proinsulin and proglucagon synthe- 
sis starts at 1 to $2 \mathrm{mmol} / 1$ while a half-maximal effect is observed at around $5 \mathrm{mmol} / 1$ of L-arginine in the medium (Fig.2). Again, there is no comparable action on prosomatostatin formation.

As may already be concluded from the data of Figure 1 , the degree of inhibition on proinsulin by this amino acid is modulated by the concentration of glucose. Figure $3 \mathrm{~A}$ shows the known effect of glucose on proinsulin formation with a gradual increase between 2.5 and $20 \mathrm{mmol} / 1$. Formation of other islet proteins, except proglucagon, is also stimulated. Although there

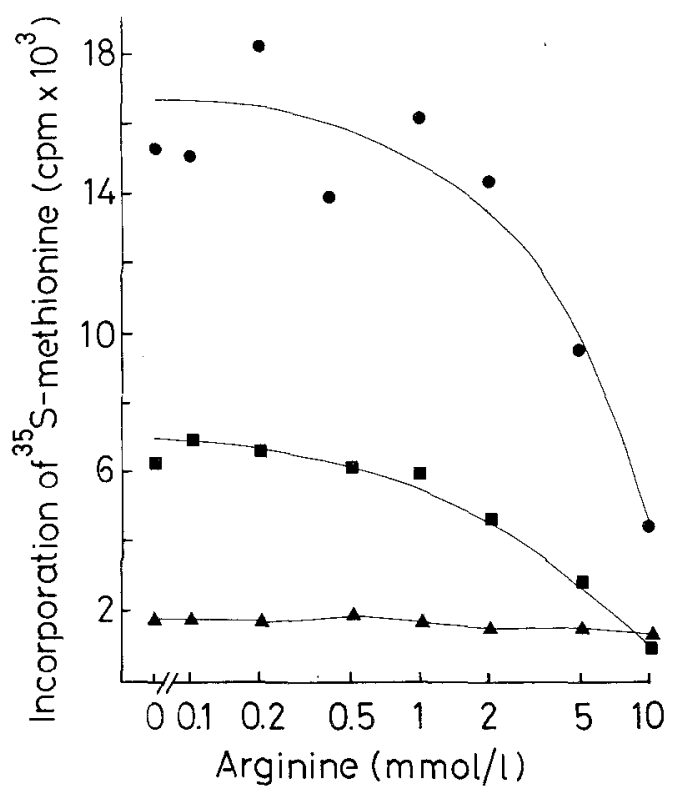

Fig. 2. Concentration-dependency of the effect of arginine on prohormone biosynthesis in pancreatic islets. Samples of 100 islets were preincubated for $60 \mathrm{~min}$ without $\mathrm{L}$-arginine as indicated followed by incubation with $\left.{ }^{35} \mathrm{~S}\right)$ methionine for $10 \mathrm{~min}$. Glucose concentration: $7.5 \mathrm{mmol} / \mathrm{l}$. (Each point represents mean values from 3 experiments). Symbols are as in Figure 1 appears to be some increase in Figure $3 \mathrm{~A}$, incorporation of label into the prosomatostatin band was not reproducibly influenced by glucose in accordance with previous observations [6]. In the presence of $10 \mathrm{mmol} / 1$ of L-arginine inhibition of proinsulin synthesis is complete at $2.5 \mathrm{mmol} / 1$ of glucose but appears to be gradually diminished by raising the glucose concentration up to $20 \mathrm{mmol} / 1$ (Fig. 3 A). Most of the other islet proteins largely behave like proinsulin, whereas proglucagon inhibition is not reversed by high glucose.

The antagonistic action of arginine and glucose on proinsulin biosynthesis is shown in more detail in Figure $3 \mathrm{~B}$, where the degree of inhibition is expressed in relation to the respective control experiments. At low glucose $(2.5 \mathrm{mmol} / 1)$ already 0.1 to $0.2 \mathrm{mmol} / 1$ of L-arginine show some inhibitory action while 2 to $5 \mathrm{mmol} / 1$ depress proinsulin formation completely. At high glucose $(20 \mathrm{mmol} / \mathrm{l})$ the inhibitory action of arginine up to $10 \mathrm{mmol} / \mathrm{l}$ is entirely abolished.

The influence of other cationic amino acids on prohormone formation is summarised in Table 1. L-lysine was found to be as efficient in inhibiting the formation of proinsulin and proglucagon as L-arginine, whereas L-ornithine was slightly less active. D-arginine and especially D-lysine were less inhibitory than their respective stereo-isomers. In agreement with preceding experiments on the effect of L-arginine, the formation of prosomatostatin was not reproducibly influenced by any of these amino acids (Table 1 ).

Neutral and anionic amino acids were similarly tested at $10 \mathrm{mmol} / \mathrm{l}$ or, in case of poorly soluble amino acids, at saturating concentrations. Some neutral amino acids, i.e. leucine, phenylalanine and cysteine, strongly interfere with the incorporation of $\left({ }^{35} \mathrm{~S}\right)$ methionine into islet proteins. However, this effect differs from that of cationic amino acids since also the labelling of prosomatostatin is depressed. Moreover, in the
A

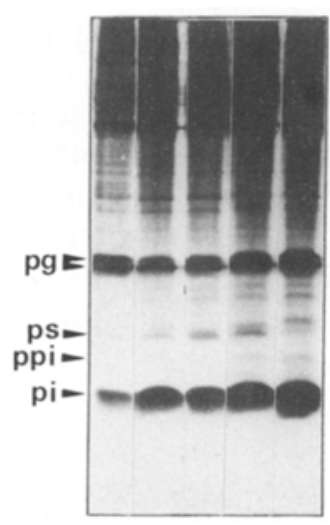

$\begin{array}{lllllllllll}\text { glucose } & 2.5 & 5 & 10 & 15 & 20 & 2.5 & 5 & 10 & 15 & 20\end{array}$ ( $\mathrm{mmol} / \mathrm{l})$ arginine $(10 \mathrm{mmol} / \mathrm{1})$

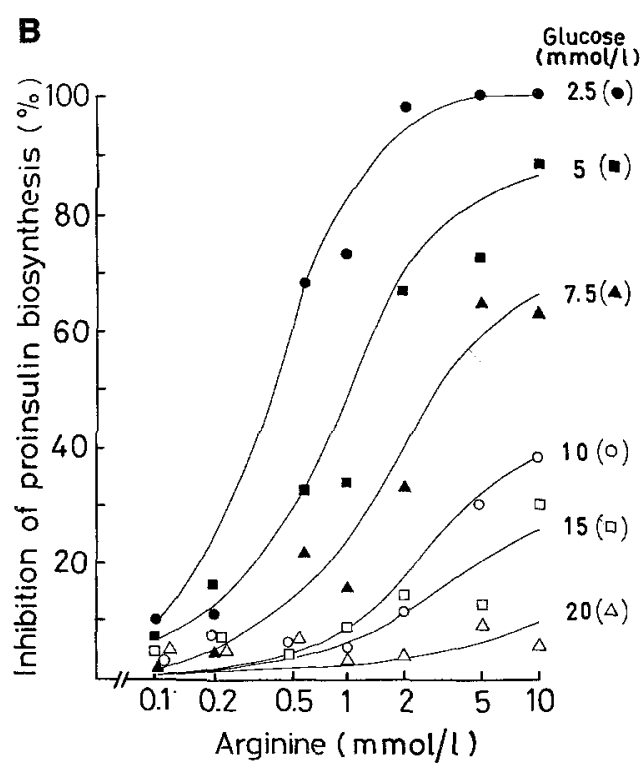

Fig. 3. Influence of glucose on arginine-mediated inhibition of proinsulin biosynthesis. Batches of 100 islets were preincubated for $60 \mathrm{~min}$ in L-arginine and glucose as indicated followed by incubation with $\left({ }^{35} \mathrm{~S}\right)$ methinonine for $10 \mathrm{~min}$. A Fluorograph, $\mathbf{B}$ quantitation of a series of experiments performed at various concentrations of arginine and glucose (means of 2 experiments). Abbreviations are as in Figure 1 
Table 1. Effect of various cationic amino acids on prohormone biosynthesis in pancreatic islets

\begin{tabular}{llcl}
\hline $\begin{array}{l}\text { Additions } \\
(10 \mathrm{mmol} / \mathrm{l})\end{array}$ & \multicolumn{3}{l}{$\begin{array}{l}\text { Incorporation of }\left({ }^{35} \mathrm{~S}\right) \text { methionine } \\
\text { islets })\end{array}$} \\
\cline { 2 - 4 } & Proinsulin & Proglucagon & Prosomatostatin \\
\hline None & $28012 \pm 849$ & $12604 \pm 689$ & $3083 \pm 329$ \\
L-arginine & $11894 \pm 830^{\mathrm{c}}$ & $2354 \pm 551^{\mathrm{c}}$ & $2632 \pm 405 \mathrm{NS}$ \\
L-lysine & $13274 \pm 816^{\mathrm{c}}$ & $2663 \pm 357^{\mathrm{c}}$ & $2664 \pm 605 \mathrm{NS}$ \\
L-ornithine & $17778 \pm 1344^{\mathrm{b}}$ & $5555 \pm 807^{\mathrm{b}}$ & $2098 \pm 395 \mathrm{NS}$ \\
D-arginine & $16486 \pm 911^{\mathrm{c}}$ & $4935 \pm 870^{\mathrm{b}}$ & $2367 \pm 298 \mathrm{NS}$ \\
D-lysine & $25085 \pm 1697 \mathrm{NS}$ & $9365 \pm 956^{\mathrm{a}}$ & $2808 \pm 500 \mathrm{NS}$ \\
\hline
\end{tabular}

Samples of 100 islets were incubated with the indicated amino acid for $60 \mathrm{~min}$ followed by incubation with $\left.{ }^{35} \mathrm{~S}\right)$ methionine for $10 \mathrm{~min}$. Glucose concentration: $7.5 \mathrm{mmol} / 1 .{ }^{\mathrm{a}} p<0.02 ;{ }^{\mathrm{b}} p<0.001 ;{ }^{\mathrm{c}} p<$ 0.0001 . NS: not significantly different from control values. Data are expressed as means \pm standard error

Table 2. Effect of cationic amino acids on the uptake of $\left({ }^{35} \mathrm{~S}\right)$ methionine into pancreatic islets

\begin{tabular}{ll}
\hline Additions $(10 \mathrm{mmol} / \mathrm{l})$ & $\begin{array}{l}\text { Uptake of }\left({ }^{35} \mathrm{~S}\right) \text { methionine }(n=6) \\
\left(\mathrm{cpm} \times 10^{3} / 100 \text { islets }\right)\end{array}$ \\
\hline None & $332 \pm 12.9$ \\
L-arginine & $308 \pm 19.3 \mathrm{NS}$ \\
L-lysine & $324 \pm 15.0 \mathrm{NS}$ \\
\hline
\end{tabular}

Determination of $\left({ }^{35} \mathrm{~S}\right)$ methionine uptake into islets is described under Materials and methods. NS: not significantly different from control values. Data are expressed as means \pm standard error

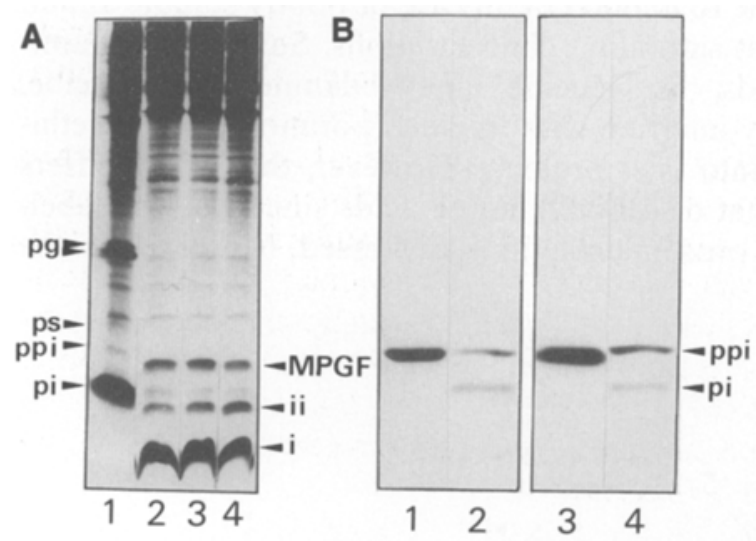

Fig. 4. A Influence of arginine and lysine on prohormone conversion in pancreatic islets. Column 1:100 islets after 10 min incubation in $\left({ }^{35}\right.$ S)methionine (pulse); Column 2: like 1, with subsequent chaseperiod for $90 \mathrm{~min}$; Column 3: like 2, with $10 \mathrm{mmol} / 1$ of L-arginine present during the chase-period; Column 4: like 2, with $10 \mathrm{mmol} / \mathrm{l}$ of L-lysine present during the chase-period. Glucose concentration: $7.5 \mathrm{mmol} / \mathrm{l}$. MPGF: major proglucagon fragment; ii: intermediate of proinsulin conversion; $\mathrm{i}$ : insulin chains. Other abbreviations are as in Figure 1. B Influence of arginine on cell-free synthesis and conversion of preproinsulin, Rat islet mRNA was translated in a wheat germ system in the absence (left panel) or presence (right panel) of $10 \mathrm{mmol} / \mathrm{l}$ of L-arginine. Translation products were precipitated with insulin antiserum and analysed as described under Materials and methods. Columns 1 and 3: immunoprecipitates from samples incubated without membranes; Columns 2 and 4: immunoprecipitates from samples incubated in the presence of microsomal membranes. Abbreviations are as in Figure 1 case of proinsulin, there is no protective effect of glucose to be observed.

These neutral amino acids are likely to interfere with the carrier-mediated transport of $\left({ }^{35}\right.$-S)methionine into islet cells in contrast to cationic amino acids. As shown by the data of Table 2, there was no significant reduction of the uptake of labelled methionine by either arginine or lysine at the highest concentrations employed in this study, i. e. $10 \mathrm{mmol} / 1$.

In order to get more insight into the mechanism by which cationic amino acids depress protein synthesis in islets, an influence on prohormone conversion was first considered. The possible inhibition of the converting protease(s) may result in the accumulation of unprocessed prohormones and a concomitant slow-down of protein translation. For conversion studies, islets were incubated for a short period in $\left({ }^{35} \mathrm{~S}\right)$ methionine (pulse) followed by chase-incubation in excess unlabelled methionine for $90 \mathrm{~min}$. As is evident from Figure $4 \mathrm{~A}$, neither arginine nor lysine have any effect on the formation of prohormonal conversion products when present only during the chase-period. Those products are for proinsulin the insulin chains (i) and an intermediate (ii) which presumably represents the B-chain with the adherent C-peptide resulting from incomplete proinsulin conversion. In case of proglucagon, the major proglucagon fragment (MPGF) [13, 14] is resolved as a conspicuous conversion product, whereas glucagon itself will migrate at the position of the insulin chains.

From fluorographs in Figures 1 and 3 it is evident that arginine does not induce any important change in the ratio of preproinsulin to proinsulin. Nevertheless, it is conceivable that the described alterations of prohormone synthesis are due to an interference with anchoring and transport of the signal peptide across the endoplasmic reticulum. For this process, cationic amino acids near the $\mathrm{N}$-terminus of the signal peptide are assumed to play a functional role [15]. Therefore, it may be speculated that an excess of free arginine and lysine will competitively occupy anionic binding sites, thus interfering with the vectorial discharge of the nascent peptide chain into the endoplasmic reticulum and bringing protein synthesis to a halt.

To test for this possibility, islet mRNA was translated in a wheat germ extract for the cell-free synthesis of preproinsulin. As shown in Figure 4B, arginine does not influence the formation of preproinsulin in the cell-free system nor does it interfere with its partial conversion to proinsulin by microsomal membranes.

\section{Discussion}

From the reported experiments it is possible to make some statements concerning the site of action of cationic amino acids within islet cells. An interference with the uptake of labelled methionine appears rather 
unlikely, merely by considering the time-course of the effect of arginine. In confirmation of this assumption, the direct measurement of this uptake into pancreatic islets does not show any significant change in the presence of cationic amino acids. The respective data of Table 2 are in agreement with the observation of Lin [16] in that only arginine concentrations higher than $10 \mathrm{mmol} / 1$ interfere with the transport of neutral amino acids.

Focussing thus on intracellular actions of arginine and lysine on the biosynthetic pathway of islet proteins, an inhibition of the various steps in the processing of hormonal precursor can also be excluded. Therefore, the process proper of protein synthesis seems to be influenced. The rapidity of this effect (Fig.1) points to the translational rather than to the transcriptional level.

There is so far no clear evidence that the reported action of cationic amino acids is limited to pancreatic islets. Nevertheless, some of the present data point to a certain tissue specificity. Thus, the cell-free translational system derived from wheat germ is not sensitive to the inhibitory action of arginine. In addition, the relative insensitivity of prosomatostatin formation suggests that suppression of translational activity by cationic amino acids may not be a general phenomenon.

The only features common to those inhibitory amino acids listed in Table 1 are the positive net charge and a rather long side chain. The comparatively lower action of the respective D-stereoisomers may be explained by their impaired affinity to carrier system $y^{+}$ [17] known as the ubiquitous transport system for arginine and lysine across the cell membrane. Although these amino acids are usually called "basic", there will hardly result any $\mathrm{pH}$-changes from fluctuations of their intracellular levels. pK-values of the guanidinoand the $\varepsilon$-amino-group are so far above the intracellular $\mathrm{pH}$-range that these amino acids will not act as bases under physiological conditions. Rather, they may influence the cationic homeostasis within the cell. However, the role of cations in regulating protein synthesis in islets is not quite clear at present. $\mathrm{Ca}^{++}$-ions appear not to be important for the regulation of insulin biosynthesis [18], whereas removal of $\mathrm{K}^{+}$-ions from incubation media results in reduced proinsulin formation [19]. The increased efflux of potassium ions provoked by cationic amino acids [20] seems to support a crucial role of $\mathrm{K}^{+}$in mediating their inhibitory effect. Whether this efflux closely follows the concentrationdependency of the arginine effect on proinsulin formation and also the counteraction by glucose remains unknown.

Finally, the question arises whether the reported effects of cationic amino acids are of any physiological importance. There are no data available on the direct measurement of arginine and lysine concentrations in normal islets. In many other tissues, arginine concentrations between 0.1 and $0.2 \mathrm{mmol} / \mathrm{l}$ have been report- ed, whereas concentrations of lysine were found to be somewhat higher, i.e. between 0.2 and $0.8 \mathrm{mmol} / 1$ [21]. In extrapolating these data to pancreatic islets, these concentrations would be too low to regulate the formation of proglucagon. However, they would suffice to influence the synthesis of proinsulin, at least at low glucose concentrations. The fluorographs of Figure 1 suggest that proinsulin formation is repressed at low glucose as compared to other islet prohormones. For such a comparison, the presence of only one methionine residue in rat proinsulin II [22] but of two such residues in proglucagon [23] and prosomatostatin [24], respectively, has to be taken into consideration. On the other hand, the resulting differences in the degree of biosynthetic labelling are compensated by the preponderance of the insulin-producing B cell in islets [25].

In discussing the possible physiological role, two other observations may be important: (1) Arginine and glucose exert their antagonistic action in a similar molar range (Fig. $3 \mathrm{~B}$ ). (2) The time-course of proinsulin inhibition by arginine and its reversal is very similar to that of the rapid translational control by glucose [26] (unpublished data).

From these findings it is hypothesised that cationic amino acids and glucose, or rather a still unidentified metabolite of it, act stoichiometrically as antagonists on proinsulin synthesis. Thus, at low glucose, the physiological levels of cationic amino acids repress proinsulin formation. Increasing glucose supply will lead to a gradual derepression. The concomitantly increased conversion of proinsulin will raise the concentrations of arginine and lysine. Provided these amino acids pass the secretory vesicle membrane, they may exert a feed-back control on insulin synthesis.

Whether $\mathrm{K}^{+}$is the integral regulator or whether the respective metabolites act more directly on the translational process will have to be studied in more detail. Intact cells with their various compartments and metabolic activities are by far too complex models to untangle these molecular mechanisms. For this purpose, a cell-free translational system that is partially or entirely reconstituted from components of pancreatic islets will be necessary.

Acknowledgements. The skillful technical assistance of Ms. B.Fuchs is gratefully acknowledget. This work was supported by a grant from the Wilhelm Sander-Stiftung, Neustadt/Donau, FRG.

\section{References}

1. Steiner DF, Quinn PS, Chan SJ, Marsh J, Tager HS (1980) Processing mechanisms in the biosynthesis of proteins. Ann NY Acad Sci 343: 1-16

2. Gerich JE, Charles MA, Grodsky GM (1976) Regulation of pancreatic insulin and glucagon secretion. Ann Rev Physiol 38: 353-388

3. Schatz H, Nierle C, Pfeiffer EF (1975) (Pro)Insulin biosynthesis and release of newly synthesised (pro)insulin from isolated islets 
from rat pancreas in the presence of amino acids and sulfonylureas. Eur J Clin Invest 5:477-485

4. Hellerstrom C, Howell SL, Edwards JC, Andersson A (1972) An investigation of glucagon biosynthesis in isolated pancreatic islets of guinea pigs. FEBS Lett 27: 97-101

5. Patzelt C, Labrecque AD, Duguid JR, Carroll RJ, Keim PS, Heinrikson RL, Steiner DF (1978) Detection and kinetic behavior of preproinsulin in pancreatic islets. Proc Natl Acad Sci USA 75: $1260-1264$

6. Patzelt C, Tager HS, Carroll RJ, Steiner DF (1979) Identification and processing of proglucagon in pancreatic islets. Nature 282: 260-266

7. Patzelt C, Tager HS, Carroll RJ, Steiner DF (1980) Identification of prosomatostatin in pancreatic islets. Proc Natl Acad Sci USA 77: $2410-2414$

8. Rodes CJ, Lucas CA, Halban PA (1987) Glucose stimulates the biosynthesis of rat I and II insulin to an equal extent in isolated pancreatic islets. FEBS Lett 215: 179-182

9. Lernmark A, Nathans A, Steiner DF (1976) Preparation and characterization of plasma-membrane enriched fractions from rat pancreatic islets. J Cell Biol 71: 606-623

10. McKinney RM, Spillane JT, Pearce GW (1966) A simple method for determining the labeling efficiency of fluorescein isothiocyanate products. Anal Biochem 14: 421-428

11. Mazjoub JA, Kronenberg HM, Potts JT, Rich A, Habener JF (1979) Identification and cell-free translation of mRNA coding for a precursor of parathyroid secretory protein. J Biol Chem 254: 7449-7455

12. Jackson RC, Blobel G (1977) Post-translational cleavage of presecretory proteins with an extract of rough microsomes from dog pancreas containing signal peptidase activity. Proc Natl Acad Sci USA 74: 5598-5602

13. Patzelt C, Schiltz E (1984) Conversion of proglucagon in pancreatic alpha cells: the major endproducts are glucagon and a single peptide, the major proglucagon fragment, that contains two glucagon-like sequences. Proc Natl Acad Sci USA 81: 5007-5011

14. Patzelt C, Schug G (1981) The major proglucagon fragment: an abundant islet protein and secretory product. FEBS Lett 129: $127-130$

15. Inouye $S$, Soberon X, Franceschini T, Nakamura K, Itakura K, Inouye M (1982) Role of positive charge on the aminoterminal region of the signal peptide in protein secretion across the membrane. Proc Natl Acad Sci USA 79: 3438-3441

16. Lin BJ (1977) An apparent inhibition of insulin biosynthesis resulting from inhibition of transport of neutral amino acids by arginine. Diabetologia 13: 77-82
17. White MF (1985) The transport of cationic amino acids across the plasma membrane of mamalian cells. Biochim Biophys Acta 722: $255-374$

18. Steiner DF, Kemmler W, Clark JL, Oyer PE, Rubenstein AH (1972) The biosynthesis of insulin. In: Steiner DF, Freinkel N (eds) Handbook of Physiology-Endocrinology I. Williams and Wilkins, Baltimore, pp 175-198

19. Sener A, Malaisse WJ (1980) The stimulus-secretion coupling of glucose-induced insulin release, XXXIX. Long term effects of $\mathrm{K}^{+}$deprevation upon insulin biosynthesis and release. Endocrinology 106: 778-785

20. Charles S, Tamagawa T, Henquin J-C (1982) A single mechanism for the stimulation of insulin release and ${ }^{86} \mathrm{Rb}^{+}$efflux from rat islets by cationic amino acids. Biochem $\mathrm{J}$ 208: 301-308

21. Herbert JD, Coulson RA, Hernandez T (1966) Free amino acids in the caiman and rat. Comp Biochem Physiol 17: 583-589

22. Steiner DF, Clark JL, Nolan C, Rubenstein AH, Margoliash E, Aten B, Oyer PE (1969) Proinsulin in the biosynthesis of insulin. In: Astwood EB (ed) Recent progress in hormone research, Vol 25. Academic Press, New York, pp 207-282

23. Heinrich G, Gross P, Lund PK, Bentley RC, Habener JF (1984) Pre-proglucagon messenger ribonucleic acid: nucleotide and encoded amino acid sequences of the rat pancreatic complementary deoyribonucleic acid. Endocrinology 115: 2176-2181

24. Goodman RH, Aron DC, Roos BA (1983) Rat pre-prosomatostatin. Structure and processing by microsomal membranes. $\mathbf{J}$ Biol Chem 258: 5570-5573

25. Orci L, Baetens D, Rufener C, Amherdt M, Ravazzola M, Studer P, Malaisse-Lagae F, Unger RH (1976) Hypertrophy and hyperplasia of somatostatin-containing $\mathrm{D}$-cells in diabeto. Proc Natl Acad Sci USA 73: 1338-1342

26. Ashcroft SJH, Bunce J, Lowry M, Hansen SE, Hedeskov CJ (1978) The effects of sugars on (pro)insulin biosynthesis. Biochem J 174: 517-526

Received: 25 May 1987

and in revised form: 2 February 1988

Dr. C. Patzelt

Physiologisch-Chemisches Institut

Koellikerstraße 2

D-8700 Würzburg

FRG 